\title{
Production of Bone-resorbing Activity and Colony-stimulating Activity In Vivo and In Vitro by a Human Squamous Cell Carcinoma Associated with Hypercalcemia and Leukocytosis
}

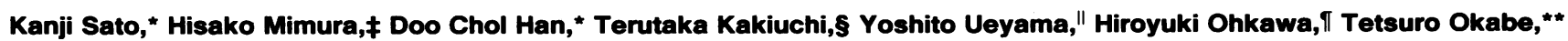 \\ Yukio Kondo, ** Nakaaki Ohsawa,** Toshio Tsushima," and Kazuo Shizume* \\ *Department of Medicine, Institute of Clinical Endocrinology, Tokyo Women's Medical College, Kawadacho 10, Shinjuku-ku, Tokyo; \\ $\ddagger$ Foundation of Growth Science, Shinjuku-ku, Tokyo; §Department of Allergology, Institute of Medical Science, University of Tokyo, \\ Minato-ku, Tokyo; "Central Institute for Experimental Animal Research, ICentral Research Laboratories, Chugai Pharmaceutical Co., \\ Ltd., Tokyo; and ${ }^{* *}$ The Third Department of Internal Medicine, University of Tokyo, Japan
}

\begin{abstract}
A squamous cell carcinoma of 33-yr-old patient who developed marked leukocytosis and hypercalcemia was transplanted into nude mice in which more marked leukocytosis and hypercalcemia also developed. This tumor (LJC-1-JCK) produced a colonystimulating factor (CSF) and formed a cyst in the tumor from which a CSF-producing cell line (T3M-1) was established. The CSF causes predominantly formation of granulocytic colonies in addition to macrophage colonies.

Bone-resorbing activity (BRA) was detected in the cystic fluid and was eluted as two separate peaks with proteins of an apparent molecular weight of 30,000-50,000 and 10,000-20,000. Colonystimulating activity (CSA) was eluted at an apparent $30,000 \mathrm{~mol}$ wt. The conditioned medium of the T3M-1 cells also contained a BRA with an apparent 14,000 mol wt, whereas CSA eluted at an apparent 30,000 mol wt. PTH, epidermal growth factor, transforming growth factor-alpha, prostaglandin Es, and vitamin $D$ could not account for the powerful BRA. In contrast to CSA, BRA was not inactivated by trypsin and more stable at $70^{\circ} \mathrm{C}$. When T3M-1 cells were transplanted into nude mice, marked hypercalcemia developed in addition to granulocytosis.

Our findings suggest that the tumor produces and secretes a powerful BRA in vivo and in vitro, which is different from CSA in terms of molecular weight, heat stability, and trypsin treatment. We speculate that the synergistic action of CSF that stimulates macrophage colony formation and recruits osteoclast precursors, and BRA, which stimulates mononuclear phagocytes and/or osteoclasts were responsible for a marked increase in osteoclastic bone resorption and humoral hypercalcemia in the patient.
\end{abstract}

\section{Introduction}

In Japan there are several case reports of patients with malignant solid tumors in whom marked leukocytosis and severe hyper-

Part of this work was presented at the 7th Asia and Oceania Congress of Endocrinology, Tokyo, 1982 (Abstract 341), the VIIIth International Conference on Calcium Regulating Hormones, Kobe, Japan, 16-24 October, 1983, and the 7th International Congress of Endocrinology, Quebec, Canada, 1-7 July, 1984 (Abstract 2236).

Address reprint requests to Dr. Sato.

Received for publication 6 November 1984 and in revised form 20 November 1985.

J. Clin. Invest.

(C) The American Society for Clinical Investigation, Inc.

$0021-9738 / 86 / 07 / 0145 / 10 \$ 1.00$

Volume 78, July 1986, 145-154 calcemia developed (1-5). Three of these tumors have been serially transplanted in nude mice and maintained for several years by Ohsawa, Kondo, and Ueyama $(2,6)$. Very interestingly, leukocytosis as well as hypercalcemia invariably developed in the tumor-bearing mice $(2,5,6)$. One of these tumors is a squamous cell carcinoma (LJC-1-JCK), which originated from a submandibular tumor of a 33-yr-old patient with leukocytosis $\left(\sim 100,000 / \mathrm{mm}^{3}\right)$ and hypercalcemia $(\sim 15 \mathrm{mg} / \mathrm{dl})$ at the terminal stage $(1,2)$. This tumor forms a cyst and always causes marked leukocytosis $\left(\sim 300,000 / \mathrm{mm}^{3}\right)$ and hypercalcemia $(\sim 20$ $\mathrm{mg} / \mathrm{dl})$ as it grows in nude mice. The mechanism of granulocytosis was elucidated by Asano et al. (1), who demonstrated that the tumor secreted a colony-stimulating factor (CSF) ${ }^{1}$ effective on bone marrow cells of human as well as mice. Recently, a CSF-producing cell line (T3M-1) was established from the tumor (7). The CSF produced stimulates bone marrow cells to form predominantly granulocytic colonies $(>80 \%)$ and macrophage colonies $(<6 \%$ ) in vitro $(8)$. In the previous report $(2)$, we demonstrated that the extirpation of the tumor was accompanied by rapid normalization of leukocytosis and hypercalcemia, suggesting that the hypercalcemia is humorally mediated and not due to bone metastasis. Morphological examination of the hypercalcemic, tumor-bearing mice revealed a marked osteoclastic bone resorption. Furthermore, serum immunoreactive parathyroid hormone (iPTH) levels in the hypercalcemic nude mice and the patient were not elevated. These findings suggest that these animals are a suitable experimental model for studies of humoral hypercalcemia of malignancy of human $(2,5)$.

The hypercalcemia of malignancy is due to increased osteoclastic bone resorption (9). The factors responsible in the majority of cases are unknown but not due to PTH. They are likely due to osteoclast-activating factor (OAF), and 1,25-dihydroxyvitamin $\mathrm{D}_{3}\left(1,25-(\mathrm{OH})_{2}-\mathrm{D}_{3}\right)$ in certain hematologic malignancies, or factors that bind to the parathyroid hormone receptor, prostaglandins, and transforming growth factors (TGF) in solid tumors without bone metastasis (9). Since osteoclasts are believed to derive from cells of the monocyte-phagocyte series $(10,11)$, and since CSF stimulates proliferation and differentiation of granulocyte and macrophages (12), it is tempting to speculate that CSF may also affect bone macrophage, and stimulate osteoclastic bone resorption. On the assumption that granulocytosis and hy-

1. Abbreviations used in this paper: BRA, bone-resorbing activity; CSA, colony-stimulating activity; CSF, colony-stimulating factor; EGF, epidermal growth factor; g, granulocyte; IL-1, interleukin 1; iPTH, immunoreactive parathyroid hormone; LPS, lipopolysaccharide; $M$, macrophage; OAF, osteoclast-activating factor; PDGF, platelet-derived growth factor; PGE, prostaglandin E; PTH, parathyroid hormone; TGF, transforming growth factor. 
percalcemia are somehow related, we examined cystic fluid from tumor LJC-1-JCK and conditioned medium of T3M-1 cells by an in vitro method for bone-resorbing activity (BRA) and compared it with colony-stimulating activity (CSA).

\section{Methods}

Source of tumor and cells. Tumor LJC-1-JCK was a squamous cell carcinoma that was associated with hypercalcemia and granulocytosis both in the patient and in nude mice bearing the tumor $(1,2)$. The methods for transplanting the tumor into nude mice have been described before. A CSF-producing cell line (T3M-1 cell) was established from the tumor (7).

Preparation of samples. Cystic fluid was aspirated from the tumor through a large needle. Usually $0.3-0.6 \mathrm{ml}$ of fluid was obtained from 1 to $2 \mathrm{~g}$ tumor of hypercalcemic nude mice. Combined cystic fluid was centrifuged at $10,000 \mathrm{~g}$ for $30 \mathrm{~min}$ and stored at $-20^{\circ} \mathrm{C}$ until assayed.

When T3M-1 cells became confluent, culture medium was replaced with a fresh F-10 medium supplemented with $5 \%$ fetal calf serum, penicillin $(100 \mathrm{U} / \mathrm{ml})$, and streptomycin $(100 \mu \mathrm{g} / \mathrm{ml})$, and cultured further for 3-7 d. The spent medium was harvested, centrifuged at 3,000 rpm for $20 \mathrm{~min}$, and stored at $-20^{\circ} \mathrm{C}$ until assayed. The conditioned medium of T3M-1 cells (50-120 ml) was concentrated 10-15-fold by ultrafiltration, using PM-10 membrane.

Gel chromatography. Cystic fluid $(5 \mathrm{ml})$ of tumor LJC-1-JCK and concentrated conditioned medium of T3M-1 cells $(6 \mathrm{ml})$ were applied to a column of Sephadex G-100 $(2.2 \times 83 \mathrm{~cm})$ equilibrated with $0.9 \%$ $\mathrm{NaCl}$ solution containing $1 \mathrm{mM}$ sodium phosphate buffer ( $\mathrm{pH} 7.4$ ). Eluates were collected in $5 \mathrm{ml} /$ tube; $0.1 \mathrm{ml}$ of eluates were taken for measurement of protein (13). Then, $0.1 \mathrm{ml}$ of bovine serum albumin (BSA) was added to all the eluates to a final concentration of $0.2 \%$. All samples were dialyzed against $100 \mathrm{vol}$ of BGJ medium (Fitton-Jackson Modification, Gibco, Grand Island, NY) at $4^{\circ} \mathrm{C}$ overnight $(15-20 \mathrm{~h})$. The dialysis membrane used was boiled Spectrapor 3 (Spectrum Medical Industries Inc., Los Angeles, CA), with a nominal molecular weight cutoff of 3,500. Before assay samples were sterilized by filtering through a millipore filter (Milex GS, $0.22 \mu \mathrm{m}$, Millipore Corp., Bedford, MA). In some experiments, conditioned medium of T3M-1 cells was applied to a column of Sephadex G-75 $(2.2 \times 83 \mathrm{~cm})$ equilibrated with $0.9 \%$ saline containing $1 \mathrm{mM}$ sodium phosphate buffer and $0.02 \%$ Tween 20 . Eluates were collected in $5.5 \mathrm{ml} /$ tube and were extensively dialyzed against $0.9 \%$ saline containing $1 \mathrm{mM}$ sodium phosphate buffer, penicillin $(100 \mathrm{U} / \mathrm{ml})$ and streptomycin $(100 \mu \mathrm{g} / \mathrm{ml})$, then dialyzed against BGJ medium as described above. To each retentate, $0.1 \mathrm{ml}$ of BSA solution $(10 \mathrm{mg} / \mathrm{ml})$, which also had been dialyzed against BGJ medium, was added and then filtered through a millipore filter. Samples were stored at $4^{\circ} \mathrm{C}$ until assayed for CSA, BRA, transforming activity, and interleukin 1 (IL-1) activity.

$B R A$. BRA was assessed using modifications of the method of Raisz $(14,15)$. Pregnant mice (strain ICR) were injected subcutaneously with $10 \mu \mathrm{Ci}$ of ${ }^{45} \mathrm{Ca}$ on the 16 th $\mathrm{d}$ of the gestation. On the $17 \mathrm{th} \mathrm{d}$, the fetuses were removed, the shafts of the radius and ulna were dissected and cultured in BGJ medium. After a 24- or 48-h period of preculture, the bones were transferred to test or control media for assay. Control values for ${ }^{45} \mathrm{Ca}$ release were obtained by culturing bones in BGJ medium containing $0.2 \%$ BSA or the first fractions from Sephadex column (tubes 1-3) that had been processed exactly as samples as described above. After $3 \mathrm{~d}$ in culture, ${ }^{45} \mathrm{Ca}$ release from bones in the test medium was compared to ${ }^{45} \mathrm{Ca}$ release in control culture. The percentage release of ${ }^{45} \mathrm{Ca}$ was determined by measuring radioactivity in both bone and medium and was calculated as follows: percent release $=($ medium $\mathrm{dpm} /$ medium $\mathrm{dpm}+$ bone $\mathrm{dpm}) \times 100$. All assays were performed in quadruplicate using bones from four fetuses. Statistical significance was analyzed by Student's $t$ test. The minimum hPTH (1-34), prostaglandin $E_{1}$, and 1,25-dihydroxycholecalciferol $\left(1,25-(\mathrm{OH})_{2}-\mathrm{D}_{3}\right)$ concentrations to elicit a significant BRA were $4 \mathrm{ng} / \mathrm{ml}, 10^{-8} \mathrm{M}$, and $10^{-10} \mathrm{M}$, respectively in our laboratory (16). Epidermal growth factor (EGF) $(1-10 \mathrm{ng} / \mathrm{ml}$ ) could not elicit any significant BRA during $3 \mathrm{~d}$ of culture. In some experiments, fetal bones cultured for $3 \mathrm{~d}$ in eluates of the cystic fluid were fixed in $10 \%$ formalin, decalcified by formic acid, and stained with hematoxylin and eosin.
CSA. CSA was assessed by the methylcellulose method using mouse bone marrow cells with slight modifications $(17,18)$. In short, $2 \mathrm{ml}$ of $2.2 \%$ methylcellulose (Methocell powder, $4,000 \mathrm{cps}$, Dow Chemical Co., Midland, MI) in Dulbecco-Vogt medium, $1 \mathrm{ml}$ of horse serum (Gibco), 0.5-1.0 ml of samples (Sephadex column eluates of the cystic fluid or the conditioned medium of T3M-1 cells), $0-0.5 \mathrm{ml}$ of BGJ medium to adjust to total volume to $5.0 \mathrm{ml}$, and $25-30 \times 10^{4}$ mouse bone marrow cells suspended in $1 \mathrm{ml}$ of BGJ medium were mixed well, and $1 \mathrm{ml}$ of the mixture was plated in two to four tissue culture dishes $(35 \times 10 \mathrm{~mm}$, Falcon Labware, Oxnard, CA). Incubation was carried out at $37^{\circ} \mathrm{C}$ in $5 \% \mathrm{CO}_{2}$ and $95 \%$ air. On day 7 , the number of colonies (40 cells or more) was counted using an inverted microscope and CSA was expressed by numbers of colonies formed per 50,000 bone marrow cells for the cystic fluid and per 60,000 bone marrow cells for the T3M-1 cell-conditioned medium. In some experiments, each colony was aspirated by utilizing a 10- $\mu$ l Eppendorf pipette under direct microscope visualization and cells were stained with May-Giemsa method.

IL-1. IL-1 activity was measured in the $\mathrm{C} 3 \mathrm{H} / \mathrm{HeJ}$ mouse thymocyte mitogenesis assay as described previously (19). Briefly, thymocytes (1.5 $\times 10^{6}$ cells/well) from 5- to 9-wk-old $\mathrm{C} 3 \mathrm{H} / \mathrm{HeJ}$ mice (obtained from Jackson Laboratory, Bar Harbor, ME, and bred in our laboratory) were cultured in $200 \mu \mathrm{l}$ RPMI 1640 medium containing $10 \%$ fetal calf serum, $100 \mu \mathrm{g} / \mathrm{ml}$ kanamycin and $5 \times 10^{-5} \mathrm{M}$ mercaptoethanol in the presence of dilutions of test samples. After $3 \mathrm{~d}$ of culture, thymidine incorporation was measured by the addition of $\left[{ }^{3} \mathrm{H}\right]$ thymidine $(0.25 \mu \mathrm{Ci}) 6 \mathrm{~h}$ before harvest. Results of triplicate assay were expressed as mean $\pm \mathrm{SD}$. Culture supernatant of a macrophage hybridoma stimulated with lipopolysaccharide (LPS; $5 \mu \mathrm{g} / \mathrm{ml}$ ) was used as an IL-1-containing supernatant. The macrophage hybridoma was produced as described (20).

$T G F$ activity. Transforming activity was measured by the stimulation of normal anchorage-dependent rat kidney fibroblasts (NRK cells, clone 49F) to form colonies in soft agar (21). In brief, samples (0.1-0.2 ml) were suspended in $0.3 \%$ agar (Difco Laboratories, Detroit, MI; Noble agar) in Dulbecco's modified Eagle's medium (Gibco) supplemented with $10 \%$ calf serum, penicillin $(100 \mathrm{U} / \mathrm{ml})$, and streptomycin $(100 \mu \mathrm{g} / \mathrm{ml})$ and containing $5 \times 10^{3}$ cells $/ \mathrm{ml}$. A portion $(0.5 \mathrm{ml})$ of the resultant mixture was pipetted onto a $0.5-\mathrm{ml}$ base layer $(0.6 \%$ agar in the supplemented medium) in multi-well plates ( $\phi: 23 \mathrm{~mm}$, Linbro Chemicals, Hamden, CT). Plates were then incubated at $37^{\circ} \mathrm{C}$ for $7 \mathrm{~d}$ in a humidified $5 \% \mathrm{CO}_{2}$ atmosphere without further feeding. The assay was read unstained and unfixed at $1 \mathrm{wk}$ and transforming activity was expressed by the number of colonies ( $>20$ cells) in a $1-\mathrm{cm}^{2}$ field.

Measurement of iPTH, prostaglandins, vitamin D metabolites, and $E G F$. iPTH concentrations in the fractions with BRA of the cystic fluid were determined by radioimmunoassay kits (Eiken Corp., Tokyo) using antiserum specific for $\mathrm{COOH}$ - and $\mathrm{NH}_{2}$-terminal regions. Normal serum PTH levels determined by $\mathrm{COOH}$ - and $\mathrm{NH}_{2}$-terminal radioimmunoassay are $0.3-1.1 \mathrm{ng} / \mathrm{ml}$ and $<0.6 \mathrm{ng} / \mathrm{ml}$, respectively.

Prostaglandin E (PGE) concentrations in the cystic fluid were measured by a radioimmunoassay kit (Clinical Assays, Cambridge, MA) (22) at Tokyo Clinical Laboratory (Tokyo). The assay measures both prostaglandin $E_{1}$ and $E_{2}$. Each is converted to $P_{G B}$ and $P B_{2}$, respectively, by alkaline treatment. The antibody, while primarily binding $\mathrm{PGB}_{1}$, also binds $\mathrm{PGB}_{2}$ by the $23 \%$ cross-reactivity. The antibody only slightly crossreacts with $\mathrm{PGF}_{1 \alpha}$ or $\mathrm{PGF}_{2 \alpha}(<0.23 \%)$. Normal PGE concentrations in serum are $<230 \mathrm{pg} / \mathrm{ml}$.

Vitamin D metabolite concentrations in the cystic fluid were mea sured at the Chugai Pharmaceutical Co. by competitive protein binding assay and radioreceptor assay $(23,24)$. Normal serum concentrations of 25-hydroxyvitamin D (25-OH-D), 24,25-dihydroxyvitamin D (24,25$\left.(\mathrm{OH})_{2}-\mathrm{D}\right)$, and 1,25-dihydroxyvitamin $\mathrm{D}\left(1,25-(\mathrm{OH})_{2}-\mathrm{D}\right)$ in the rat (Fisher stain) serum are $18.7 \pm 2.9 \mathrm{ng} / \mathrm{ml}, 2.24 \pm 1.04 \mathrm{ng} / \mathrm{ml}$, and $130 \pm 11.1 \mathrm{pg} /$ $\mathrm{ml}(n=6$, mean $\pm \mathrm{SD})$, respectively. The normal vitamin $\mathrm{D}$ concentration of nude mouse serum is not known, because of difficulties of collecting enough serum for assay.

EGF in the eluates of T3M-1 cell-conditioned medium was assessed by radioreceptor assay using human placental membrane fraction as matrix. Minimum detectable doses of mEGF was $<1 \mathrm{ng} / \mathrm{ml}(25)$.

Effects of indomethacin and glucocorticoid on BRA and prostaglandin 
$E$ release from cultured fetal bones. In several experiments, fetal mouse bones labeled with ${ }^{45} \mathrm{Ca}$ were cultured in the control fraction (tubes 15 ) or in the fractions with BRA (tubes 43-48, Fig. 3). In each sample, indomethacin or hydrocortisone dissolved in ethanol was added to final concentrations of $10^{-8}-10^{-5} \mathrm{M}$. The same dose of ethanol was added to control cultures. The final ethanol concentration did not exceed $0.1 \%$. After $3 \mathrm{~d}$ of culture, ${ }^{45} \mathrm{Ca}$ release from the fetal bones was assessed as described above.

To investigate the amount of PGE produced in the fetal bones and released into the culture medium, fetal mouse bones that had not been labeled with ${ }^{45} \mathrm{Ca}$ were cultured in the control (tubes $1-5$ ), fractions with BRA (tubes 43-48) and the same fractions containing $10^{-6} \mathrm{M}$ indomethacin. After $3 \mathrm{~d}$ of culture, spent culture medium $(0.5 \mathrm{ml} /$ well $)$ from four fetal bones was combined and stored at $-20^{\circ} \mathrm{C}$. PGE concentrations in these combined conditioned media were determined by a radioimmunoassay kit as described above (22).

Heat stability. Eluates containing BRA (tubes 44-48, Fig. 3) and CSA (tubes 34-39) of the T3M-1 cell-conditioned medium were pooled and heated for $30 \mathrm{~min}$ in a water bath at various temperatures. Then, samples $(5 \mathrm{ml})$ were cooled, and $0.1 \mathrm{ml}$ of $10 \%$ BSA solution was added. They were dialyzed against BGJ medium and assayed for BRA and CSA.

Effect of proteolytic enzyme. Control eluates (tubes 1-3, and 58-60) and eluates containing BRA (tubes 44-48, Fig. 3) and CSA (tubes 3538) were incubated with bovine trypsin $(5 \mu \mathrm{g} / \mathrm{ml} ; 15,042 \mathrm{SU} / \mathrm{mg}, \mathrm{Cal}-$ biochem-Behring Corp., La Jolla, CA) in $0.9 \% \mathrm{NaCl}$ solution containing $1 \mathrm{mM}$ sodium phosphate buffer ( $\mathrm{pH} 7.4$ ) for $2 \mathrm{~h}$ at $37^{\circ} \mathrm{C}$. The reaction was terminated by the addition of trypsin inhibitor $(20 \mu \mathrm{g} / \mathrm{ml}$, from soya bean, 6,000-8,000 BAEE U/mg, BDH Chemicals Ltd., Poole, England), then BSA was added to a final concentration of $0.2 \%$. Simultaneously, half of these combined eluates were incubated first with the same dose of trypsin inhibitor $(20 \mu \mathrm{g} / \mathrm{ml})$. After $2 \mathrm{~h}$ incubtion at $37^{\circ} \mathrm{C}$, trypsin was added to $5 \mu \mathrm{g} / \mathrm{ml}$, followed by the addition of BSA to a final concentration of $0.2 \%$. All samples were dialyzed against BGJ medium and assayed for BRA and CSA.

Transplantation of T3M-1 cells to nude mice. CSF-producing T3M1 cells were transplanted subcutaneously in the flanks of nude mice. When the tumor grew to more than $1 \mathrm{~g}$ and the tumor-bearing nude mice started to lose weight, they were anesthetized with ether and blood was taken from the abdominal aorta. Peripheral blood leukocytes were counted by hemocytometer and serum calcium concentration was measured by colorimetric assay kits (Yatoron Ltd., Tokyo). The tumor-bearing nude mice were immersed in $10 \%$ formalin. Shafts of the femurs were decalcified and stained with hematoxylin and eosin.

Histodynamic studies of bones of control and tumor-bearing nude mice. The tumor LC-1-JCK was inoculated into the right flank of five nude mice weighing $\sim 25 \mathrm{~g}$ at the age of $16 \mathrm{wk}$. 7 and $8 \mathrm{~d}$ after the transplantation, chlortetracycline $(2 \mathrm{mg} / 100 \mathrm{~g}$ body weight $)$ was administered intraperitoneally into five control (17 wk old) and five tumorbearing nude mice. 16 and $17 \mathrm{~d}$ after the transplantation, calcein $(0.8$ $\mathrm{mg} / 100 \mathrm{~g}$ body weight, obtained from Nakarai Chemicals Ltd., Tokyo) was administered intraperitoneally into both groups. After an additional five days, mice were killed. Left femurs were removed and fixed in $70 \%$ ethanol, dehydrated in graded ethanol, stained with Villanueva's bone stain for $3 \mathrm{~d}$ and embedded in methylmethacrylate. Undecalcified bone sections of about $40 \mu \mathrm{m}$ were prepared by cutting with a crystal cutter (MC-202, Maruto Co., Ltd., Tokyo) and grinding with sand paper. These sections were mounted with Eukitt's media (Calibrated Instrument Inc., Ardsley, NY), and tetracycline and calcein uptakes at the mineralization front in the periosteum were studied by a fluorescent microscopy.

\section{Results}

$B R A$ and CSA in the cystic fluid. Tumor cystic fluid, when unfractionated, showed only slight BRA (data not shown). However, when it was chromatographed on a Sephadex G-100 column, much greater BRAs were demonstrated at a molecular weight of 30,000-50,000 (peak II) and 10,000-20,000 (peak III) (Fig. 1, upper panel). The tumor extract also contained a slight BRA corresponding to peak III (data: not shown). In other experiments, the BRA in the peak III was stronger than that in the peak II. A slight BRA at the void volume (peak I) was variable; old cystic fluid stored at $-20^{\circ} \mathrm{C}$ for $1-2$ yr contained a higher BRA at the void volume, but a fresh one showed a small activity as shown in Fig. 1. Prostaglandin E levels in the cystic fluid was only $924 \mathrm{pg} / \mathrm{ml}$ and no BRA was detected at the total bed volume.

As reported previously $(1,5)$, the cystic fluid contained a striking CSA: the main CSA eluted at the molecular weight of $\sim 30,000$, with a weak peak of the activity at the molecular weight of 15,000 (Fig. 1 B). Although BRA and CSA eluted in broad peaks, it should be pointed out that the tubes 46,47 , and 48 , in which the strongest BRA was present, contained little or no CSA. Morphologic examination of cells aspirated from the colonies revealed that most of the colonies were consisted of granulocytes as described previously (8).

Fetal mouse forearm bones co-cultured with the peak III of the cystic fluid was almost completely (95\%) resorbed during 3d culture. When this bone was examined histologically, the bone was completely resorbed (Fig. 2) and the bone remnant was full of osteoclasts.

$B R A$ and CSA in the conditioned medium. When nonconditioned medium $(60 \mathrm{ml})$ containing $5 \%$ FCS was concentrated

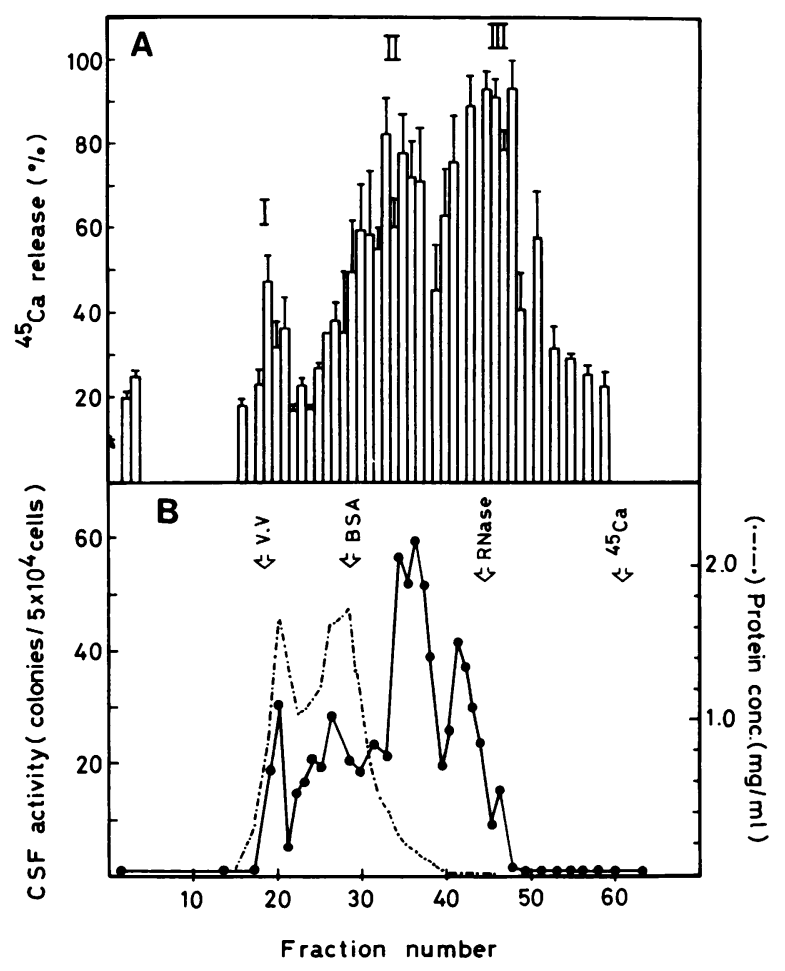

Figure 1. BRA and CSA of the cystic fluid in the eluate from Sephadex G-100 column. $5 \mathrm{ml}$ of the cystic fluid was applied on a Sephadex G-100 column and eluted with $0.9 \% \mathrm{NaCl}$ solution containing 1 $\mathrm{mM}$ phosphate buffer ( $\mathrm{pH} \mathrm{7.4)}$ and fractionated in $5 \mathrm{ml} /$ tube. An aliquot $(0.1 \mathrm{ml})$ was taken for measurement of protein concentration $(\cdot-\cdot-\cdot)$ and $0.1 \mathrm{ml}$ of $10 \% \mathrm{BSA}$ was added to each eluate. Then each eluate was dialyzed against $\mathrm{BGJ}$ medium and assayed for BRA $(A)$ and CSA $(B)$ as described in the method. BRA was assessed by percentage of ${ }^{45} \mathrm{Ca}$ released into the medium during $3 \mathrm{~d}$ of culture. Data are mean \pm SD of quadruplicate assay. CSA was expressed by the numbers of colonies formed per $5 \times 10^{4}$ mouse bone marrow cells during $7 \mathrm{~d}$ of culture. Results are the mean of duplicate. The column markers are blue dextran for void volume (V.V.), BSA $(67,000)$, ribonuclease (RNase, 13,700) and ${ }^{45} \mathrm{Ca}(45)$. 

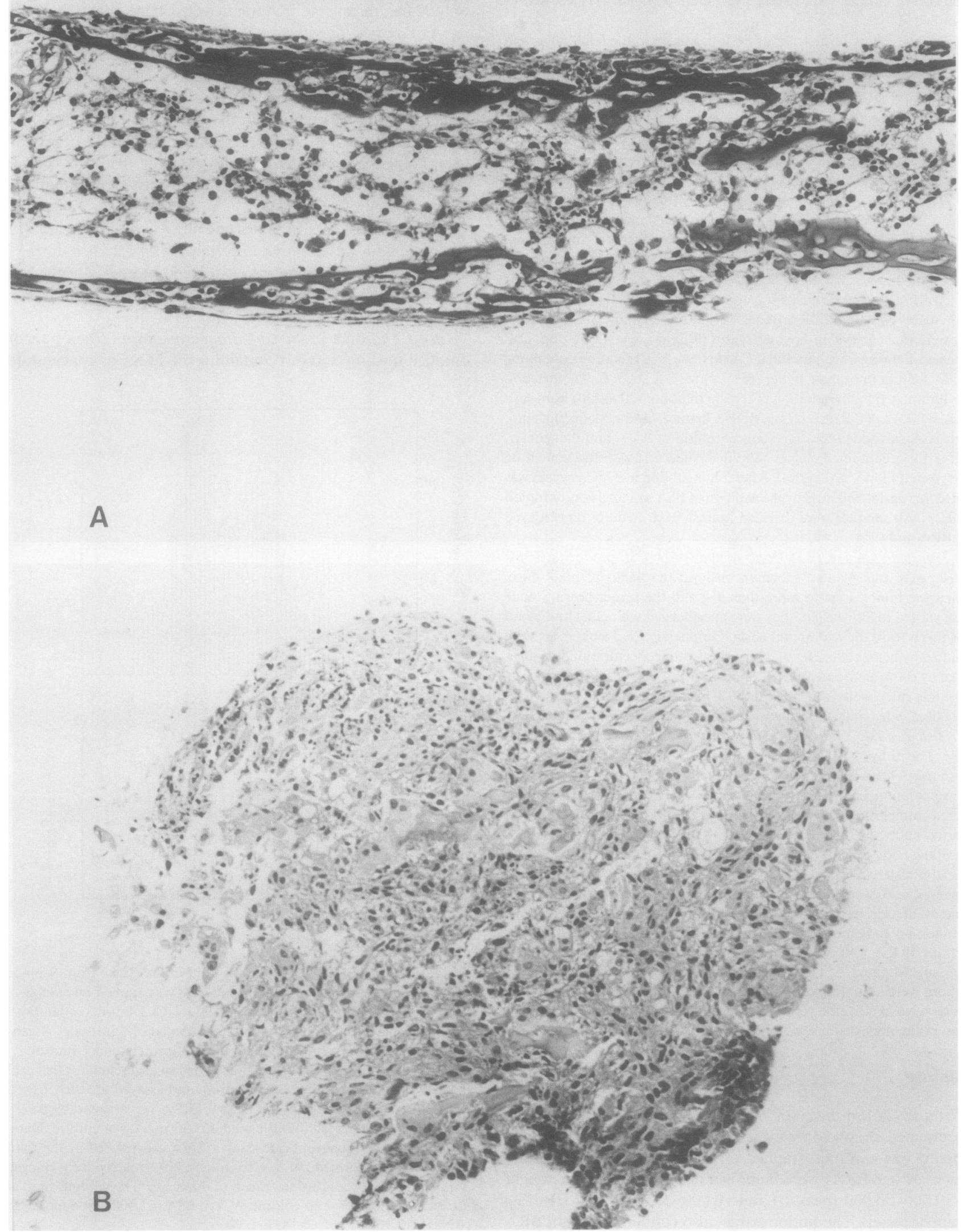
and applied to a Sephadex G-100 column, a slight BRA was demonstrated in fractions $18-30$, in which macromolecular proteins greater than BSA with BRA $(26,27)$ were eluted. However, no significant BRA was detected in other fractions. Nonconditioned medium did not have any CSA.

The unfractionated T3M-1 cell-conditioned medium, when extensively dialyzed against BGJ medium, contained a slight but significant BRA (data not shown) compared with the nonconditioned medium. The activity was stronger when the cells were cultured for 6-7 d than for $3 \mathrm{~d}$. When the culture medium conditioned by T3M-1 cells for $6 \mathrm{~d}(60-100 \mathrm{ml})$ was concentrated and applied to Sephadex G-100 column, a powerful BRA was demonstrated in fractions 44-48 with an apparent molecular weight of 14,000 , which exactly corresponds to the BRA of peak III in the cystic fluid (Figs. 1 and 3). No BRA was detected near the void volume, however, a slight BRA was frequently detected in the tubes numbered 36-40. To investigate whether the conditioned medium contained inhibitors for BRA, submaximal dose of $1,25-(\mathrm{OH})_{2}-\mathrm{D}_{3}$ was added to each eluate to a final concentration of $10^{-9} \mathrm{M}$. The BRA induced by $1,25-(\mathrm{OH})_{2}-\mathrm{D}_{3}$ was distinctly suppressed around the region where BSA was eluted (data not shown).

When Tween 20 was not added to the elution buffer (Fig. 3), CSA was eluted in three peaks. As reported previously (8), the main CSA was eluted in fractions 34-39 with an apparent molecular weight of 30,000 (peak B), which corresponds to the main CSA in the cystic fluid. Furthermore, a small peak was noted in fractions 41-45 after the main peak as was in the cystic fluid (Figs. 1 and 3). The apparent molecular weight of this peak was about 15,000 . This peak $C$ was variable and dependent on the lot of the conditioned medium: some lots did not contain peak $C$. In addition, another peak was detected before BSA. This peak (peak A) tended to be higher, the more the conditioned medium was concentrated.

When the samples were applied to a Sephadex G-75 column and eluted with a Tween 20-containing buffer (Fig. 4), CSA was eluted in only peaks B and C; peak A disappeared completely, suggesting that peak A (Fig. 3) was due to aggregates of CSF or CSF bound nonspecifically to serum proteins. BRA was eluted in the region with an apparent molecular weight of 10,00020,000 , where little or no CSA was detected. These findings suggest that BRA resides in the macromolecular factor different from CSF.

$I L-1$ activity. When $50 \mu 1$ of the fractions 36-39 with CSA and fractions 44-49 with BRA (Fig. 3) were added to mouse thymocyte culture, proliferative response of thymocytes was $138 \pm 7$ and $226 \pm 102 \mathrm{cpm}$, respectively. Thymocyte proliferation induced by $25-\mu \mathrm{l}$ culture supernatant of a macrophage hybridoma, a positive IL-1 control, was $22,481 \pm 1,785 \mathrm{cpm}$. LPS $(0.25$ $\mu \mathrm{g})$ did not induce any significant proliferation. Background incorporation was $138 \pm 55 \mathrm{cpm}$. These results demonstrate that direct IL-1 activity in the fractions with BRA is very low, if any.

Transforming activity. Two distinct peaks of TGF activity were detected in the eluates of the T3M-1 cell-conditioned medium (Fig. 4). The major peak was eluted near the void volume. There was another peak of activity in tubes $27-35$, with an ap-

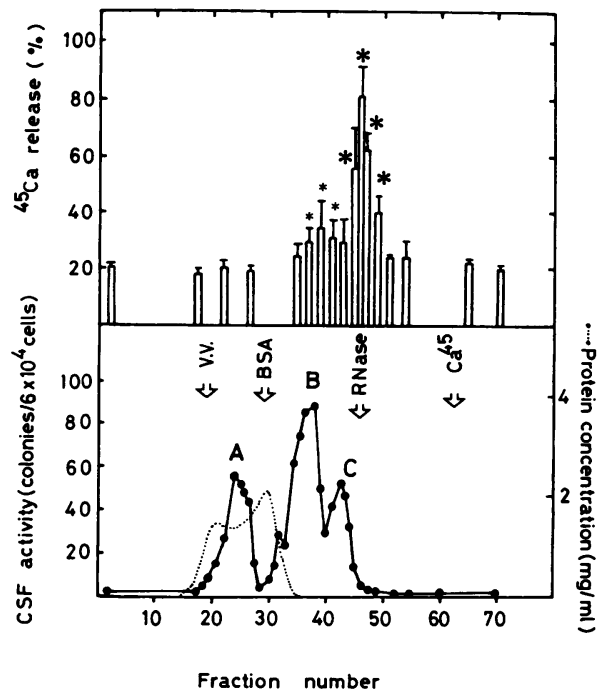

Figure 3. BRA and CSA in the T3M-1 cell-conditioned medium. The conditioned medium was obtained by culturing T3M-1 cells with F-10 medium supplemented with $5 \%$ bovine fetal serum for $7 \mathrm{~d}$, and stored at $-20^{\circ} \mathrm{C}$. The conditioned medium $(60 \mathrm{ml})$ was concentrated to $6 \mathrm{ml}$ by ultrafiltration, applied on a Sephadex G-100 column and eluted as described in the legend to Fig. 1. BRA was assessed by percentage of ${ }^{45} \mathrm{Ca}$ released into the medium during $3 \mathrm{~d}$ culture. Data are mean $\pm \mathrm{SD}$ of quadruplicate assay. Large and small asterisks (*, *) represent $P$ values of $<0.01$ and $<0.05$, respectively. CSA was expressed by the numbers of colonies formed per $6 \times 10^{4}$ mouse bone marrow cells during $7 \mathrm{~d}$ of culture. Results are the mean of duplicate.

parent molecular weight of $\sim 25,000$. However, no transforming activity was detected in the region (tubes $36-43$ ) where BRA was eluted.

Concentrations of $i P T H$, prostaglandins, vitamin D metabolites, and EGF. iPTH concentrations in the eluates of the cystic fluid with the highest BRA (peak III) were $0.22 \mathrm{ng} / \mathrm{ml}$ when antibody specific for the $\mathrm{COOH}$-terminal region was used. It was $0.2 \mathrm{ng} / \mathrm{ml}$ by the $\mathrm{NH}_{2}$-terminal assay. 25-OH-D, 24,25$(\mathrm{OH})_{2}-\mathrm{D}$, and $1,25-(\mathrm{OH})_{2}-\mathrm{D}$ concentrations in the cystic fluid were $8.8 \mathrm{ng} / \mathrm{ml}, 0.63 \mathrm{ng} / \mathrm{ml}$, and $49.1 \mathrm{pg} / \mathrm{ml}$, respectively. EGF concentrations in each eluate of the T3M-1 conditioned medium were all below the sensitivity of the assay $(<1 \mathrm{ng} / \mathrm{ml})$, suggesting that BRA can not be accounted for by these osteolytic substances.

Effects of glucocorticoid and indomethacin on BRA and PGE released from cultured fetal bones. BRA in the eluates of T3M1 cell-conditioned medium was almost completely inhibited by indomethacin at $10^{-7}-10^{-5} \mathrm{M}$. High concentrations of hydrocortisone $\left(10^{-6}-10^{-5} \mathrm{M}\right)$ also inhibited the BRA, but the inhibitory effect was not evident at lower concentration $\left(10^{-8} \mathrm{M}\right)$, suggesting that the activity could not be ascribed to OAF (Table I).

When PGE produced in fetal bones and released into the medium during $3 \mathrm{~d}$ of culture was measured, control medium contained $73 \pm 33 \mathrm{pg} / \mathrm{ml}$ (mean $\pm \mathrm{SD}, n=3$ ). PGE concentration in the spent medium containing BRA was $186 \pm 34 \mathrm{pg} / \mathrm{ml}$

Figure 2. Fetal mouse bones used for bioassay. A control bone $(A)$ was cultured for $3 \mathrm{~d}$ in BGJ medium containing $0.2 \%$ BSA. Another bone (B) was cultured for $3 \mathrm{~d}$ with the eluate of the peak III of the cystic fluid. Note that the latter bone was completely resorbed and that multinucleated osteoclasts abound in the bone remnant. Hematoxylin-eosin staining. $\times 80$. 


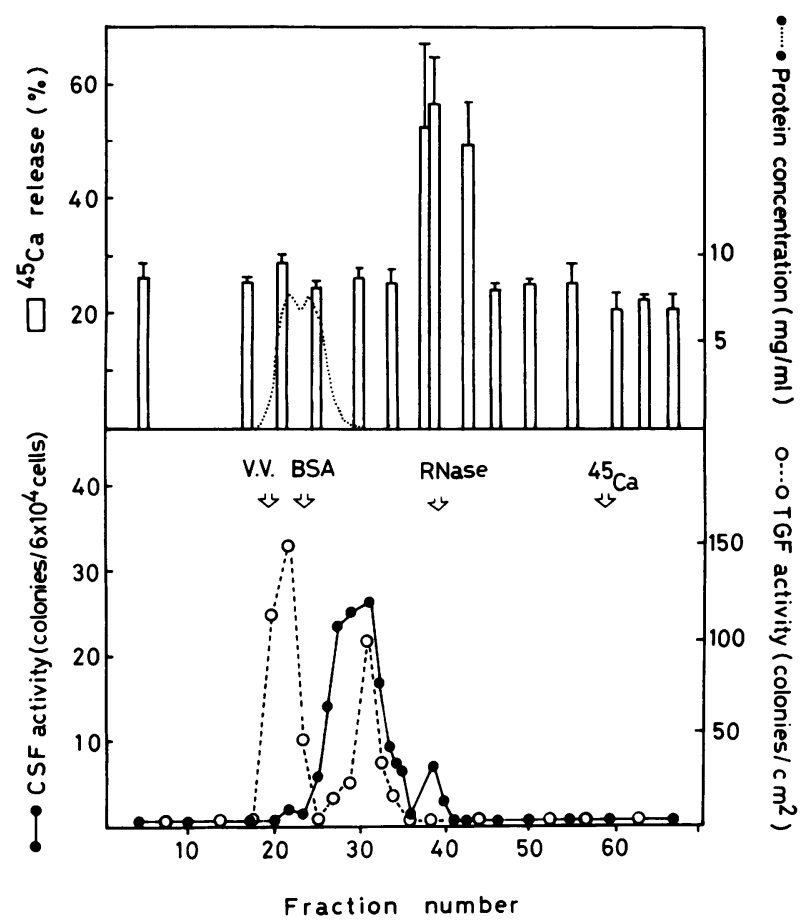

Figure 4. BRA, CSA, and transforming activity in the T3M-1 cell-conditioned medium. The conditioned medium $(120 \mathrm{ml})$ was concentrated and applied to a Sephadex G-75 column. The column was eluted with $0.9 \% \mathrm{NaCl}$ solution containing $1 \mathrm{mM}$ phosphate buffer and Tween $20(0.02 \%)$. Each eluate $(5.5 \mathrm{ml})$ was extensively dialyzed against $0.9 \% \mathrm{NaCl}$ (twice) and $\mathrm{BGJ}$ medium (once). Then $10 \% \mathrm{BSA}$ solution, which also had been dialyzed against BGJ medium, was added to each sample. Samples were filtered and stored at $4^{\circ} \mathrm{C}$ until assayed for BRA, CSA, and transforming activity as described in Methods. Data are mean \pm SD of quadruplicate assay for BRA (top), mean of duplicate for CSA (bottom: $\bullet-\bullet$ ) and transforming activity (bottom: $0---0$ ).

(mean $\pm \mathrm{SD}, n=3$ ), which was decreased to $34 \pm 16 \mathrm{pg} / \mathrm{ml}$ (mean $\pm \mathrm{SD}, n=3$ ) by the addition of $10^{-6} \mathrm{M}$ indomethacin. These findings suggest that bone resorbing factor in the T3M-1 cell-conditioned medium stimulated PGE production in fetal mouse bones during $3 \mathrm{~d}$ of culture.

Effects of heating and trypsin treatment on BRA and CSA. BRA in the eluates of T3M-1 conditioned medium was stable at least for $3 \mathrm{mo}$ when stored at $4^{\circ} \mathrm{C}$. Heating to $56^{\circ} \mathrm{C}$ for 30 min did not inactivate BRA. However, it was partially inactivated at $70^{\circ} \mathrm{C}$ and completely inactivated at $100^{\circ} \mathrm{C}$. CSA in the eluates of $\mathrm{T} 3 \mathrm{M}-1$ cell-conditioned medium was also-stable at $56^{\circ} \mathrm{C}$ but almost completely inactivated at $70^{\circ} \mathrm{C}$ (Table II).

BRA in the eluates of T3M-1 cell-conditioned medium was not inactivated by treatment with trypsin $(5 \mu \mathrm{g} / \mathrm{ml})$, whereas CSA was completely inactivated (Table III).

Transplantation of T3M-1 cells to nude mice. In order to investigate whether BRA detected in vitro in the T3M-1 cellconditioned medium was capable of inducing hypercalcemia in vivo, T3M-1 cells were transplanted into three nude mice. When the tumor grew to $\sim 1 \mathrm{~g}$, serum $\mathrm{Ca}$ concentrations were elevated to $14.9 \pm 2.9 \mathrm{mg} / \mathrm{dl}$ (mean $\pm \mathrm{SD}, n=3$ ), and peripheral blood leukocytes exceeded $50,000 / \mathrm{mm}^{3}$ in all mice. Histological examination of the shaft of the femur of these hypercalcemic nude mice revealed marked increase in osteoclastic bone resorption
Table I. Effects of Glucocorticoid and Indomethacin on Bone Resorption

\begin{tabular}{lll}
\hline & \multicolumn{2}{l}{ 45 Ca release } \\
\cline { 2 - 3 } Treatment & Fractions (1-3) & Fractions (43-48) \\
\hline & percent & percent \\
Hydrocortisone & & \\
0 & $22.3 \pm 2.6$ & $55.1 \pm 2.2$ \\
$10^{-8} \mathrm{M}$ & $22.8 \pm 1.8$ & $57.3 \pm 6.3$ \\
$10^{-7} \mathrm{M}$ & $22.8 \pm 2.0$ & $40.6 \pm 13.0$ \\
$10^{-6} \mathrm{M}$ & $23.8 \pm 2.7$ & $24.4 \pm 3.3^{*}$ \\
$10^{-5} \mathrm{M}$ & $24.0 \pm 3.6$ & $27.8 \pm 3.3^{*}$ \\
& & \\
Indomethacin & & $54.9 \pm 4.4$ \\
0 & $22.4 \pm 1.0$ & $33.1 \pm 3.0^{*}$ \\
$10^{-7} \mathrm{M}$ & $21.5 \pm 3.0$ & $36.5 \pm 9.3^{*}$ \\
$10^{-6} \mathrm{M}$ & $22.6 \pm 4.0$ & $30.8 \pm 3.3^{*}$ \\
$10^{-5} \mathrm{M}$ & $23.5 \pm 3.4$ & \\
\hline
\end{tabular}

Effects of glucocorticoid and indomethacin on BRA (fractions 43-48, Fig. 3) of T3M-1 cell-conditioned medium were studied by adding each agent to a final concentration as described above. Control bones were cultured with the eluates (fractions 1-3), which had been processed exactly as samples. All cultures were performed in quadruplicate. Data are percentage of ${ }^{45} \mathrm{Ca}($ mean $\pm \mathrm{SD})$ released into the medium during $3 \mathrm{~d}$ of culture.

$* P<0.05$.

as previously reported in the tumor (LJC-1-JCK)-bearing nude mice (2).

Histodynamic studies of bones of tumor (LJC-1-JCK)-bearing nude mice. Serum $\mathrm{Ca}$ levels in the control and tumor-bearing nude mice were $9.5 \pm 0.4$ and $16.8 \pm 2.5 \mathrm{mg} / \mathrm{dl}$ (mean $\pm \mathrm{SD}, n=5$ ), respectively.

In the control nude mice, no resorption cavity was found in the cortex of the diaphysis of the femur, and the clear double labels of tetracycline and calcein encircled the cortical bone in the whole subperiosteal (Fig. $5 \mathrm{~A}$ ), suggesting that bone formation proceeded normally in the control mice.

In contrast, the cortical bone of the tumor-bearing nude mice contained a number of resorption cavities (Fig. 5 B). Further-

Table II. Effects of Heating on BRA and CSA

\begin{tabular}{lll}
\hline Heating & BRA & CSA \\
\hline & percent & colonies $/ 6 \times 10^{\star}$ cells \\
Control & $24.2 \pm 1.9$ & $0.7 \pm 1.2$ \\
Samples & $56.4 \pm 4.5$ & $52.6 \pm 11.2$ \\
$+56^{\circ} \mathrm{C}$ & $58.7 \pm 12.0$ & $48.7 \pm 11.6$ \\
$+70^{\circ} \mathrm{C}$ & $50.8 \pm 12.9$ & $5.0 \pm 2.1^{*}$ \\
$+100^{\circ} \mathrm{C}$ & $21.3 \pm 4.7^{*}$ & $3.8 \pm 1.7^{*}$ \\
\hline
\end{tabular}

Fractions containing BRA (tubes 44-48, Fig. 3) and CSA (tubes 3539) and controls (tubes 1-4) of the T3M-1 cell-conditioned medium were heated at various temperatures in a water bath for $30 \mathrm{~min}$. After cooling to room temperature, BSA was added to a final concentration of $0.2 \%$. All samples were dialyzed against BGJ medium and assayed for BRA and CSA. All data are mean \pm SD of quadruplicate assay for BRA and triplicate assay for CSA.

${ }^{*} P<0.005$. 
Table III. Effect of Trypsin Treatment on BRA and CSA

\begin{tabular}{lll}
\hline Treatment & BRA & CSA \\
\hline & percent & colonies $/ 6 \times 10^{4}$ cells \\
A Control (tubes 1-3) & & \\
Inh $\rightarrow$ Trp & $11.4 \pm 3.0$ & 0 \\
Trp $\rightarrow$ Inh & $14.0 \pm 2.0$ & 0 \\
B Fractions with CSA & & \\
Inh $\rightarrow$ Trp & $17.7 \pm 3.3$ & $29.6 \pm 4.5$ \\
Trp $\rightarrow$ Inh & $20.5 \pm 6.8$ & 0 \\
C Fractions with BRA & & \\
Inh $\rightarrow$ Trp & $34.9 \pm 4.9$ & $1.8 \pm 1.0$ \\
Trp $\rightarrow$ Inh & $47.6 \pm 5.1$ & 0 \\
D Fractions (tubes 58-60) & & \\
Inh $\rightarrow$ Trp & $11.4 \pm 1.9$ & 0 \\
Trp $\rightarrow$ Inh & $13.1 \pm 2.0$ & 0 \\
& & \\
\hline
\end{tabular}

Trypsin (trp; $5 \mu \mathrm{g} / \mathrm{ml}$ ) was added to controls (tubes 1-3, and 58-60, Fig. 3), fractions containing BRA (tubes 44-48) and CSA (tubes 3538). After $2 \mathrm{~h}$ incubation at $37^{\circ} \mathrm{C}$, trypsin was inactivated by the addition of trypsin inhibitor (Inh; $20 \mu \mathrm{g} / \mathrm{ml}$ ). Simultaneously, half of these samples were first treated with the same dose of trypsin inhibitor (20 $\mu \mathrm{g} / \mathrm{ml})$. After $2 \mathrm{~h}$ incubation at $37^{\circ} \mathrm{C}$, the same dose of trypsin $(5 \mu \mathrm{g} /$ $\mathrm{ml}$ ) was added. Then, BSA was added to all samples to a final concentration of $0.2 \%$. Samples were dialyzed against BGJ medium and assayed for BRA and CSA. Data are mean \pm SD of quadruplicate assay for BRA and triplicate assay for CSA.

more, the clear double labels of tetracycline and calcein in the periosteal bone were distinctly diminished, suggesting the suppression of bone formation in the tumor-bearing hypercalcemic nude mice.

\section{Discussion}

CSF is a growth factor that stimulates the growth and differentiation of the granulocyte and macrophage lineages (12). Recently macrophage CSF (mCSF) (28) and granulocyte CSF (gCSF) (29), which primarily stimulate the proliferation and differentiation of macrophage and granulocyte precursors, respectively, have been purified. The tumor LJC-1-JCK as well as T3M-1 cells established from the tumor produces CSF effective on bone marrow cells of human and mouse $(1,2,8)$. The CSF produced by $\mathrm{T} 3 \mathrm{M}-1$ cells stimulates predominantly the formation of granulocyte colonies in vitro, however, macrophage colonies were also formed at higher CSF concentration in the assay (up to 6\%) (8). Therefore, we describe the CSF produced by the tumor as GmCSF until it will be purified to homogeneiety. Since osteoclasts are believed to derive from the macrophage-monocytes series $(10,11)$, it is tempting to speculate that the GmCSF also participates in the pathogenesis of humoral hypercalcemia in the tumor-bearing nude mouse and the patient. Examining simultaneously BRA and CSA in the eluates of gel chromatography, we have demonstrated that the tumor LJC-1-JCK as well as T3M-1 cells produces and secretes a powerful bone resorbing factor distinctly different from the GmCSF in terms of molecular weight, heat stability and trypsin treatment. In favor of these findings is the clinical observation that patients with marked leukocytosis with a CSF-producing tumor do not necessarily develop hypercalcemia (30).
Consistent with the recent notion that the hypercalcemia of malignancy is not due to PTH in the majority of cases (31), the serum iPTH levels of our hypercalcemic nude mice and the patient were not elevated (2). Furthermore, iPTH concentration determined by $\mathrm{NH}_{2}$-terminal assay $(0.20 \mathrm{ng} / \mathrm{ml})$ was not sufficient to elicit bone resorption; $4 \mathrm{ng} / \mathrm{ml}$ of hPTH (1-34) was a minimal concentration for PTH to elicit the activity in our laboratory (16). Another candidate for the bone resorbing factor, OAF, is also unlikely, since indomethacin could (32) and glucocorticoid at a lower concentration $\left(10^{-8} \mathrm{M}\right)$ could not (33) inhibit the BRA in the T3M-1 cell-conditioned medium. These in vitro findings are very consistent with those observed in tumorbearing nude mice as well as in another patient since prednisolone treatment failed to ameliorate the hypercalcemia $(2,3)$. Furthermore, 1,25-(OH)-D and PGE concentration in the cystic fluid, a natural conditioned medium obtained in vitro, were $49.1 \mathrm{pg} / \mathrm{ml}\left(1.1 \times 10^{-10} \mathrm{M}\right)$ and $924 \mathrm{pg} / \mathrm{ml}\left(2.6 \times 10^{-9} \mathrm{M}\right)$, respectively. Although these are the minimal concentration to elicit a significant BRA in the bioassay used (16), it is highly unlikely to account for the strong macromolecular BRA in the diluted eluates of the cystic fluid (Fig. 1).

Recently, some growth factors, such as EGF and plateletderived growth factor (PDGF), were shown to have potent BRA in vitro (34-36). The BRA produced by the tumor is neither due to EGF as determined by radioreceptor assay, nor due to PDGF since the activity was lost at $100^{\circ} \mathrm{C}$ (37). More recently, Mundy et al. $(38,39)$ found that a tumor-derived TGF is responsible for humoral hypercalcemia of malignancy. Although T3M-1 cell-conditioned medium contained TGF activity, no TGF activity was detected in the fractions with BRA. These findings suggest that this tumor produces bone resorbing factor distinctly different from TGF- $\alpha$. Whether the BRA possesses TGF- $\beta$ activity, a putative bone resorbing factor for humoral hypercalcemia (40), remains to be elucidated. Furthermore, it should also be studied whether the bone resorbing factor stimulates adenylate cyclase in renal cell membrane $(41,42)$ or cultured osteosarcoma cells (43).

The BRA produced by T3M-1 cells stimulated PGE release from cultured fetal bones and was almost completely inhibited by prostaglandin synthesis inhibitors, indomethacin $\left(10^{-7}-10^{-5}\right.$ $\mathrm{M})$ and glucocorticoid at higher concentrations $\left(10^{-6}-10^{-5} \mathrm{M}\right)$. Therefore, we assume that it stimulates bone resorption through the local stimulation of prostaglandins of the $E$ series or other metabolites of arachidonic acid in bone as reported in EGF, PDGF, TGF and some osteolytic factors derived from solid tumors $(34,36,40,44)$.

T3M-1 cells produce exactly both biological activities produced by the original tumor. Elution profile of CSA was almost identical with that of the cystic fluid: major CSA (peak B) was eluted in the same fractions 34-39 with an apparent molecular weight of 30,000 (Figs. 1 and 3). Peak $A$ in the conditioned medium appears to be aggregates of CSF or CSF bound to serum proteins nonspecifically, since this peak disappears completely when the sample was eluted in the buffer containing Tween 20 (Fig. 4) as reported previously (8). In addition, T3M-1 cells produced a powerful BRA with an apparent molecular weight of 14,000 that exactly corresponds to the peak III of the cystic fluid. A BRA of peak II, however, was not distinctly demonstrated in the conditioned medium. At present, we are unable to interpret this discrepancy in the conditioned medium obtained in vivo and in vitro, but it is likely that a cell lineage that produced 

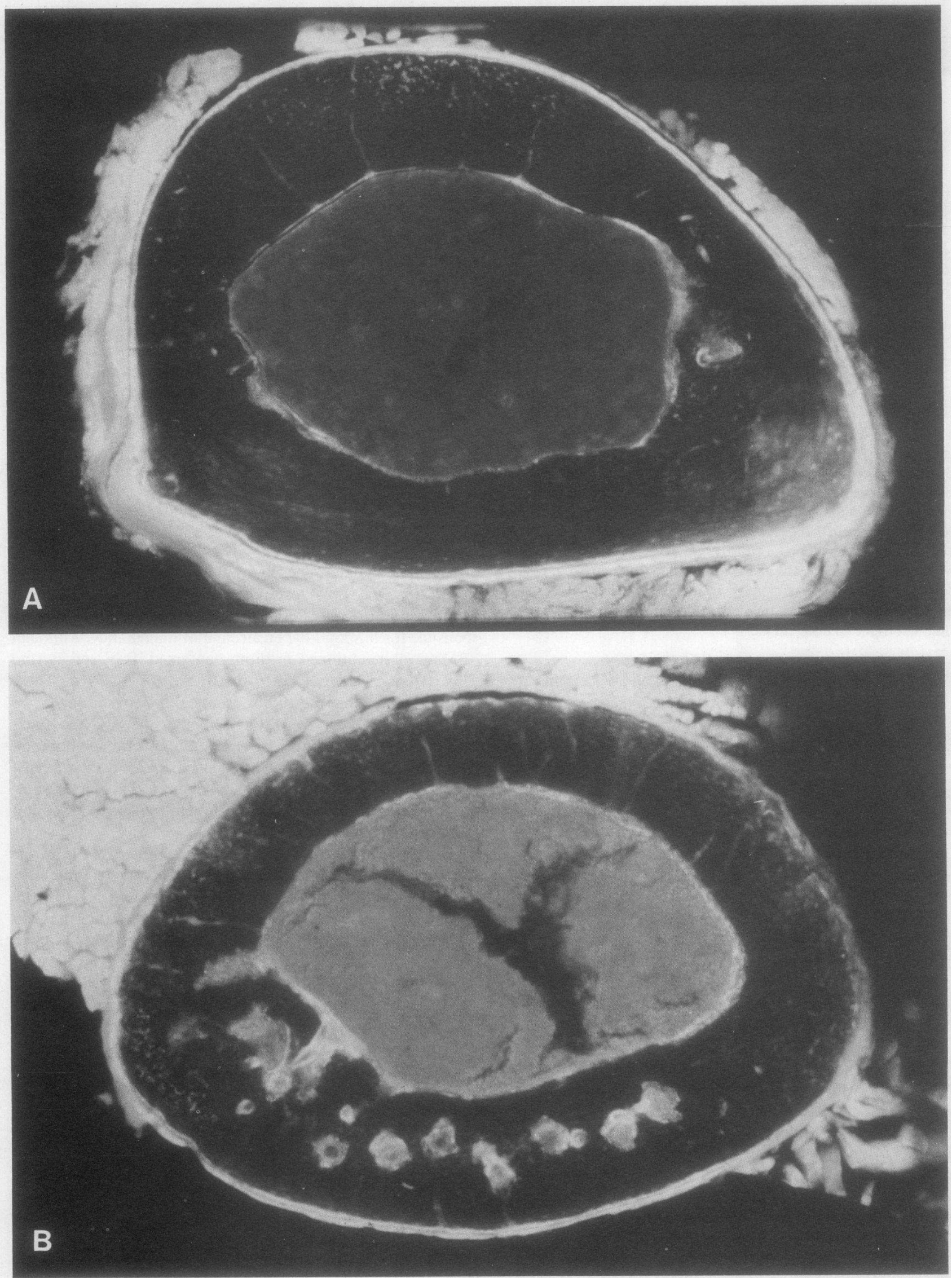

Figure 5. Histodynamic studies on femurs of control and tumor-bearing nude mice. Control nude mouse $(A)$ : Clear double label of tetracycline (inner line) and calcein (outer line) was demonstrated in the whole subperiosteal. Tumor-bearing nude mouse (B): A number of resorption cavities appear in the cortex. The double label of tetracycline and calcein was only partially observed. $\times 112$. 
the BRA of peak II had been eliminated during the cloning procedure. Another possibility will be discussed in the next paragraph. It is highly likely that peak I represents aggregates of bone resorbing factor or bone resorbing factor bound to serum protein nonspecifically, since the longer (for 1-2 yr) the cystic fluid was stored at $-20^{\circ} \mathrm{C}$, the higher activity was detected at the void volume.

It should be pointed out that a slight but significant BRA was frequently detected in the fractions containing the strongest CSA (Fig. 3). Our present data, therefore, can not absolutely exclude the possibility that $\mathrm{GmCSF}$ possesses intrinsically a weak BRA per se. In this regard, it is of interest that mCSF obtained from $L$ cell conditioned medium (28) stimulates macrophages to produce IL-1 (45), a recently identified potent bone resorbing factor (46): The bone resorbing factor produced by the tumor has a molecular weight similar to IL-1. Since the eluate with BRA contained slight IL-1 activity, we are investigating whether IL-1 activity was derived from the tumor. Furthermore it is of great interest to study whether the BRA, like mCSF, is capable of stimulating macrophages to produce IL- 1 .

Recent progress in bone research revealed that osteoclasts are derived from macrophages in the bone marrow $(10,11)$. Therefore, it is fascinating that a clonal cell established from a patient with humoral hypercalcemia of malignancy produces at least two humoral factors: a growth factor for colony-forming units in culture (CFU-C) or precursor cells committed to differentiate to granulocytes and monocytes/macrophages, and a bone resorbing factor that directly or indirectly stimulates these putative osteoclast precursors and/or osteoclasts. From the teleological point of view, the findings that the tumor produces simultaneously two factors that stimulate granulocytopoiesis and enlarge the bone marrow cavity are very interesting.

Histodynamic studies on bones in the control and tumorbearing nude mouse revealed that the bone formation in the hypercalcemic nude mouse was distinctly diminished. Similar findings were reported recently by Stewart et al. (47) who also demonstrated that bone formation rate is diminished in patients with humoral hypercalcemia of malignancy, a distinct feature different from an increased rate of bone formation in patients with primary hyperparathyroidism (47). Taking these observations together, we presume that marked increase in osteoclastic bone resorption together with decreased bone formation gives rise to marked hypercalcemia in the tumor-bearing nude mouse and probably in the patient.

In Japan, there are at least eight case reports of patients with solid tumors who developed marked leukocytosis and hypercalcemia. If pathologic manifestations, which at first seem to be totally disconnected, are found together in a sufficient series of patients, some relation between them is apparent (48). We have found that a clonal cell line established from these tumors produced CSF and bone resorbing factor in vitro, and gave rise to marked granulocytosis and hypercalcemia in vivo, respectively. We postulate that an excessive production by the tumor of GmCSF, which recruits osteoclast precursors, and of bone resorbing factor, which affects these precursor cells and stimulates osteoclastic bone resorption, caused synergistically hypercalcemia in the tumor-bearing nude mice and patients as well. Therefore, we presume that hypercalcemia and leukocytosis in some patients with solid CSF-producing tumors may constitute a new paraneoplastic syndrome $(2,5)$. Although such cases are mostly reported in Japan, a similar paraneoplastic syndrome was reported in a few patients in the United States $(49,50)$ and also in the mouse (51).

\section{Acknowledgments}

The authors thank Dr. L. G. Raisz, University of Connecticut, and Dr. G. R. Mundy, the University of Texas Health Center, San Antonio, for teaching us (K.S.) the bioassay for bone resorption from April to June, 1980. The authors are furthermore grateful to Dr. G. R. Mundy for advice in revising the manuscript. We also are indebted to Dr. Yasuho Nishii, Chugai Pharmaceutical Co., Ltd., for measuring vitamin D metabolites, and Mrs. K. Matsumoto, and Miss M. Shibata for typing the manuscript.

This work was supported by the Grant-in-Aid for Scientific Research, Ministry of Education, Science, and Culture, Japan (57570877, 58571013, 59570497), the Grant-in-Aid for Cancer Research from the Ministry of Health and Welfare, Japan (60-29), a research grant from the Foundation for Growth Science in Japan (especially donations from Mrs. Toshiko Sato), a research grant for bone-regulating peptides from Chugai Pharmaceutical Co., Ltd., and a research grant from the U. S.-Japan Malnutrition Panel, 1985.

\section{References}

1. Sato, N., S. Asano, Y. Ueyama, M. Mori, T. Okabe, Y. Kondo, N. Ohsawa, and K. Kosaka. 1979. Granulocytosis and colony-stimulating activity (CSA) produced by a human squamous cell carcinoma. Cancer (Phila.). 43:605-610.

2. Kondo, Y., K. Sato, H. Ohkawa, Y. Ueyama, T. Okabe, N. Sato, S. Asano, M. Mori, N. Ohsawa, and K. Kosaka. 1983. Association of hypercalcemia with tumors producing colony-stimulating factor(s). Cancer Res. 43:2368-2374.

3. Saito, K., Y. Kuratomi, K. Yamamoto, T. Saito, T. Kuzuya, S. Yoshida, S. Moriyama, and A. Takahashi. 1981. Primary squamous cell carcinoma of the thyroid associated with marked leukocytosis and hypercalcemia. Cancer (Phila.). 48:2080-2083.

4. Toya, M., T. Kuroda, M. Obuchi, T. Ikawa, K. Habu, and T. Ichikawa. 1981. A case report of the maxillary cancer associated with marked leukocytosis and hypercalcemia. J. Otolaryngol. Jpn. 84:15541562.

5. Sato, K., H. Mimura, Y. Ueyama, and K. Shizume. 1984. Pathogenesis of hypercalcemia in nude mice transplanted with a human colonystimulating factor (CSF)-producing tumor. A new paraneoplastic syndrome of granulocytosis and hypercalcemia. In Endocrine Control of Bone and Metabolism. Vol. 8A, International Congress Series 619. D. V. Cohn, T. Fujita, T. J. Potts, Jr., and R. V. Talmage, editors. Excerpta Medica, Amsterdam. 288-291.

6. Ohsawa, N., Y. Ueyama, K. Morita, and Y. Kondo. 1977. Heterotransplantation of human functioning tumors to nude mice. In Proceedings of the Second International Workshop on Nude Mice. T. Nomura, N. Ohsawa, N. Tamaoki, and F. Fujiwara, editors. University of Tokyo Press, Tokyo. 395-405.

7. Okabe, T., N. Sato, Y. Kondo, S. Asano, N. Ohsawa, K. Kosaka, and Y. Ueyama. 1978. Establishment and characterization of a human cancer cell line that produces human colony-stimulating factor. Cancer Res. 38:3910-3917.

8. Okabe, T., H. Nomura, N. Sato, and N. Ohsawa. 1982. Largescale production and characterization of human colony-stimulating factor. J. Cell. Physiol. 110:43-49.

9. Mundy, G. R., K. J. Ibbotson, S. M. D’Souza, E. L. Simpson, J. W. Jacobs, and T. J. Martin. 1984. The hypercalcemia of cancer. Clinical implications and pathogenic mechanism. N. Engl. J. Med. 310: 1718-1727.

10. Ash, P., J. F. Loutit, and K. M. S. Townsend. 1980. Osteoclasts derived from haematopoietic stem cells. Nature (Lond.). 283:669-670.

11. Loutit, J. F., and N. W. Nisbet. 1982. The origin of osteoclasts. Immunobiology. 161:193-203.

12. Metcalf, D. 1979. Production of colony-stimulating factors by lymphoid tissues. In Biology of the Lymphokines. S. Cohn, E. Pick, and J. J. Oppenheim, editors. Academic Press, New York. 515-540.

13. Lowry, O. H., N. J. Rosebrough, A. C. Farr, and R. J. Randall. 
1951. Protein measurement with the Folin phenol reagent. J. Biol. Chem. 193:265-275.

14. Raisz, L. G. 1965. Bone resorption in tissue culture. Factors influencing the response to parathyroid hormone. J. Clin. Invest. 44: 103-116.

15. Yoneda, T., and G. R. Mundy. 1979. Monocyte regulates osteoclast-activating factor production by releasing prostaglandins. J. Exp. Med. 150:338-350.

16. Sato, K., Y. Imamura, H. Mimura, T. Tsushima, and K. Shizume. 1982. Pathogenesis of hypercalcemia in a patient with adult $T$ cell leukemia. Bone Metab. (Jpn). 15:300-306.

17. Niho, Y. 1974. In vitro colony-formation of mouse bone marrow cells. Meneki Jikken Sosaho (Methods for Immunological Experiments). Jpn Immunological Society, Tokyo. 927-932.

18. Kimura, N., T. Shibuya, Y. Niho, H. Nakamura, S. Matsuo, T. Iamamura, N. Miyamoto, and T. Yanase. 1979. Human lung cancer cell line (NSNY) producing colony-stimulating activity which affects both human and mouse marrow cells. Gann. 70:807-810.

19. Kakiuchi, To., R. W., Chestnut, and H. M. Grey. 1983. B cell as antigen-presenting cells: The requirement for B cell activation. J. Immunol. 131:109-114.

20. Uchida, T., S. T. Ju, A. Fay, Y. N. Liu, and M. E. Dorf. 1985. Functional analysis of macrophage hybridomas. I. Production and initial characterization. J. Immunol. 134:772-778.

21. Roberts, A. B., L. C. Lamb, D. L. Newton, M. B. Sporn, J. E. DeLarco, and G. J. Todaro. 1980. Transforming growth factors: Isolation of polypeptides from virally and chemically transformed cells by acid/ ethanol extraction. Proc. Nat. Acad. Sci. USA. 77:3494-3498.

22. Levine, L., R. M. G. Cernosek, and H. V. Vunakis. 1971. Specifities of prostaglandins $B_{1}, F_{1 \alpha}$, and $F_{2 \alpha}$ antigen-antibody reaction. $J$. Biol. Chem. 246:6782-6785.

23. Shepard, R. M., R. L. Horst, A. J. Hamstra, and H. F. DeLuca. 1979. Determination of vitamin $D$ and its metabolites in plasma from normal and anephric man. Biochem. J. 182:55-59.

24. Nishii, Y., and M. Nanjo. 1981. Methods of assay of vitamin $D_{3}$. Multiple assay of vitamin D and its metabolites. Vitamins (Jpn). 55: 595-605.

25. Imai, Y., T. Tsushima, N. Sasaki, and F. Matsuzaki. 1980. Radioreceptor assay for epidermal growth factor. In Growth and Growth Factors. K. Shizume, editor. University of Tokyo Press, Tokyo. 275290.

26. Lorenzo, J. A., and L. G. Raisz. 1979. Bone resorbing activity in fetal calf serum. Calcif. Tissue Int. 28:149. (Abstr.)

27. Stern, R. H., J. C. Miller, S. F. Chen, and D. J. Klein. 1978. A bone resorbing substance from bovine serum albumin. Calcif. Tissue Int. 25:233-240.

28. Stanley, E. R., and P. M. Heard. 1977. Factors regulating macrophage production and growth. Purification and some properties of the colony-stimulating factor from medium conditioned by mouse $\mathrm{L}$ cells. J. Biol. Chem. 252:4305-4312.

29. Nicola, N. A., D. Metcalf, M. Matsumoto, and G. R. Johnson. 1983. Purification of a factor inducing differentiation in murine myelomonocytic leukemia cells. Identification as granulocyte colony-stimulating factor. J. Biol. Chem. 258:9017-9023.

30. Obara, T., Y. Ito, T. Kodama, Y. Fujimoto, H. Mizoguchi, K. Oshimi, M. Takahashi, and A. Hirakawa. 1985. A case of gastric carcinoma with excessive granulocytosis: production of a colony-stimulating factor by the tumor. Cancer (Phila.). 56:782-788.

31. Simpson, E. L., G. R. Mundy, S. M. D’Souza, K. J. Ibbotson, R. Bockman, and J. W. Jacobs. 1983. Absence of parathyroid hormone messenger RNA in nonparathyroid tumors associated with hypercalcemia. N. Engl. J. Med. 309:325-330.

32. Raisz, L. G., R. A. Luben, G. R. Mundy, J. W. Dietrich, J. E. Horton, and C. L. Trummel. 1975. Effect of osteoclast activating factor from human leukocytes on bone metabolism. J. Clin. Invest. 56:408413.

33. Strumpf, M., M. Kowalski, and G. R. Mundy. 1978. Effects of glucocorticoids on osteoclast activating factor. J. Lab. Clin. Med. 92: 772-778.
34. Tashjian, A. H., and L. Levine. 1978. Epidermal growth factor stimulates prostaglandin production and bone resorption in cultured mouse calvaria. Biochim. Biophys. Res. Commun. 85:966-975.

35. Raisz, L. G., H. A. Simmons, A. L. Sandberg, and E. Canalis. 1980. Direct stimulation of bone resorption by epidermal growth factor. Endocrinology. 107:270-273.

36. Tashjian, A. H. Jr., E. L. Hohmann, and H. N. Antoniades. 1982. Platelet-derived growth factor stimulates bone resorption via a prostaglandin-mediated mechanism. Endocrinology. 111:118-124.

37. Antoniades, H. N., D. Stathakos, C. D. Scher. 1975. Isolation of a cationic polypeptide from human serum that stimulates proliferation of 3T3 cells. Proc. Natl. Acad. Sci. USA. 72:2635-2639.

38. Ibbotson, K. J., S. M. D'Souza, K. W. Ng, C. K. Osborne, M. Niall, T. J. Martin, and G. R. Mundy. 1983. Tumor-derived growth factor increases bone resorption in a tumor associated with humoral hypercalcemia of malignancy. Science (Wash. DC). 221:1292-1294.

39. Ibbotson, K. J., D. R. Twardzik, S. M. D’Souza, W. R. Hargreaves, G. J. Todaro, and G. R. Mundy. 1985. Stimulation of bone resorption in vitro by synthetic transforming growth factor-alpha. Science (Wash. DC). 228:1007-1009.

40. Tashjian, A. H., E. F. Voelkel, M. Lazzaro, F. R. Singer, A. B. Roberts, R. Derynck, M. E. Winkler, and L. Levine. 1985. $\alpha$ and $\beta$ human transforming growth factors stimulate prostaglandin production and bone resorption in cultured mouse calvaria. Proc. Natl. Acad. Sci. USA. 82:4535-4538.

41. Stewart, A. F., K. L. Insogna, D. Goltzman, and A. E. Broadus. 1983. Identification of adenylate cyclase-stimulating activity and cytochemical glucose-6-phosphate dehydrogenase-stimulating activity in extracts of tumors from patients with humoral hypercalcemia of malignancy. Proc. Natl. Acad. Sci. USA. 80:1454-1458.

42. Strewler, G. J., R. D. Williams, and R. A. Nissensonn. 1983. Human renal carcinoma cells produce hypercalcemia in the nude mouse and a novel protein recognized by parathyroid hormone receptors. $J$. Clin. Invest. 71:769-774.

43. Rodan, S. B., K. L. Insogna, A. M. L. Vignery, A. F. Stewart, A. E. Broadus, S. M. D'Souza, D. R. Bertolini, G. R. Mundy, and G. A. Rodan. 1983. Factors associated with humoral hypercalcemia of malignancy stimulate adenylate cyclase in osteoblastic cells. J. Clin. Invest. 72:1511-1515.

44. Minkin, C., R. S. Fredericks, S. Pokress, R. K. Rude, C. F. Sharp, Jr., M. Tong, and F. R. Singer. 1981. Bone resorption and humoral hypercalcemia of malignancy. Stimulation of bone resorption in vitro by tumor extracts is inhibited by prostaglandin synthesis inhibitors. $J$. Clin. Endocrinol Metab. 53:941-947.

45. Moore, R. N., J. J. Oppenheim, J. J. Farrar, C. S. Carter, Jr., A. Waheed, and R. K. Shadduck. 1980. Production of lymphocyte-activating factor (Interleukin I) by macrophages activated with colony-stimulating factors. J. Immunol. 125:1302-1305.

46. Gowen, M., D. D. Wood, E. J. Ihrie, M. K. B. McGuire, and R. G. G. Russell. 1983. An Interleukin I like factor stimulates bone resorption in vitro. Nature (Lond.). 306:378-380.

47. Stewart, A. F., A. Vignery, A. Silverglate, N. D. Ravin, V. LiVolsi, A. E. Broadus, and R. Baron. 1982. Quantitative bone histomorphometry in humoral hypercalcemia in malignancy. Uncoupling of bone cell activity. J. Clin. Endocrinol. Metab. 55:219-227.

48. Albright, F., A. M. Butler, A. O. Hampton, and P. Smith. 1937. Syndrome characterized by osteitis fibrosa disseminata, area of pigmentation and endocrine dysfunction with precocious puberty in female. $N$. Engl. J. Med. 216:727-746.

49. Block, N. L., and W. F. Whitmore. 1973. Leukemoid reaction, thrombocytosis and hypercalcemia associated with bladder cancer. $J$. Urol. 110:660-663.

50. Hocking, W., J. Goodman, and D. Golde. 1983. Granulocytosis associated with tumor cell production of colony-stimulating activity. Blood. 61:600-603.

51. Lee, M. Y., and D. J. Baylink. 1983. Hypercalcemia, excessive bone resorption, and neutrophilia in mice bearing a mammary carcinoma. Proc. Soc. Exp. Biol. Med. 172:424-429. 